\title{
Translational medicine and its contribution to public health
}

\author{
Italla Maria Pinheiro Bezerra ${ }^{1,2}$
}

DOI: http://dx.doi.org/10.7322/jhgd.127642

\begin{abstract}
:
Introduction: Translational medicine is a new paradigm that favors a transfer of knowledge from the lab to the clinical practice. It correlates to the field of Public Health, although there are still challenges. There is a full contribution of Brazil in the theme of Translational Medicine and Public Health. These contributions to public health maximize decision making in health, which is fundamental to maintain a healthy population. Objective: Thus, the Journal of Human Growth and Development has been repository these discussions, contributing to a dissemination of this knowledge worldwide. Different aspects involving clinical practice and public health are highlighted, discussing the real situation of health conditions in the different contexts. These discussions range from the actions to promote health for the population to investigations that bring results, promoting an improvement in health and contributing to the (re)construction of health actions. The importance of researches investigating on means to get the reengineering of the health system is noted. It should consider the needs medical, researchers, managers and users in order to produce knowledge that will become products to improve the health of population.
\end{abstract}

Keywords: traslational medicine, public health, knowledge

Translational medicine is a new paradigm that propitiates the transfer of knowledge built in the experimental laboratory to clinical practice and correlates with the field of Public Health, although there are still challenges. However, several professionals from different fields of knowledge, from researchers and managers of health care area as well as students of the exact sciences, have been conducting research with this focus, from the knowledge generated in the biomedical laboratories or not, correlating to those produced in basic and applied sciences, focusing on the improvement of health services.

In this frontier of knowledge, Lean et al. ${ }^{1}$, consider translational medicine as a process that leads to evidence-based medicine to sustainable solutions to public health problems, providing longevity of populations and improving health service. To do so, it is necessary for scientists to be able, in developing research, to link basic scientific findings with the clinical research area, and to translate the results of clinical trials into transformations in clinical practice through evidence from the social sciences and policies.

The idea is to establish the connection between the creation and application of knowledge, integrating researchers from the basic and clinical areas to better assist the population. In this perspective, discussions began on the importance of clinical research so that it could transform knowledge from the basic area, since the development achieved by clinical research was not adequate to do so at the necessary speed and the efficiency. However, today there is a clear change in the speed and efficiency. Experimental laboratory research and knowledge come to application, having the University a fundamental role in this change, because it leads the knowledge to industry, or the industry will seek the knowledge in the university.

Brazil has made a wide development and contribution on the field of Translational Medicine and Public Health. These contributions maximize health decision-making that is a key factor for maintaining the health of the population, either with disease prevention, as in the case of immunizations, or with health promotion actions, aimed at improving the quality of life of the population affected or not due to health issues. The Journal of Human Growth and Development has been the repository of these discussions and also has contributed to the spread of this knowledge not only in Brazil but also around the world, doing an important effort with their publications in English which is the language of modern science.

However, the challenges to facilitate the cycle of scientific discovery from innovation in health care are still a major concern for individuals and communities seeking

\footnotetext{
1 Escola Superior de Ciências da Santa Casa de Misericórdia de Vitória, EMESCAM. Vitória, ES.

2 Laboratório de Delineamento de Estudos e Escrita Científica da Faculdade de Medicina do ABC, Santo André, SP. Corresponding author: Italla Maria Pinheiro Bezerra - E-mail: italla.bezerra@emescam.br
}

Suggested citation: Bezerra IMP. Translational medicine and its contribution to public health. J Hum Growth Dev. 2017; 27(1): 6-9. Doi: http://dx.doi.org/10.7322/jhgd.127642

Manuscript submitted: Oct 16 2016, accepted for publication Nov 142016. 
or needing health such as health professionals, decision makers, policy makers and health service funders. The interface between building knowledge to identify health improvement, pure scientific research, clinical study-based research, and finally the implementation of research results into a pragmatic outcome that is a growing source of permanent concern in clinical research and at community level. Hence, It is a vital investment that has the potential to result in dramatic improvements in overall health outcomes $^{2}$.

For Siminerio and $\mathrm{Mbanya}^{3}$ one of the major challenges of the medical and educational world currently is translational research, in order to reduce the gap between scientific knowledge and effective strategies in health care to improve patient outcomes.

Again, this dissemination of knowledge is included in the articles listed in this issue (27.1), that involves translational medicine and public health.

Research focused on growth and human developments ${ }^{4-7}$ has been highlighted and since its establishment in the 1990s it has been the central theme of this Journal. In the current issue of JHGD these studies evaluate technologies that involve the improvement of health conditions and/or issues for public health investigating the health situation of the population, especially children and adolescents ${ }^{8-10}$, which corroborate the themes in the health promotion field within the context of primary care focusing on teens and their vulnerabilities ${ }^{11-13}$, nutrition and influence on child and adolescent development ${ }^{14-18}$ and themes focused on translational medicine, describing results to improve the health indicators of the population $^{19-22}$.

With an emphasis on nutritional status, to highlight obesity in adolescents, Tebar et al. ${ }^{17}$ found the prevalence of abdominal obesity in adolescents in the city of Londrina, Paraná, Brazil, and its associated factors. It was evidenced that abdominal obesity showed a significant association with gender and high sedentary behaviour in Brazilian adolescents, independently of other factors.

The relation of bone structure and adolescent growth has been illustrated in the investigations about the relation of bone density and the practice of sports in adolescents. The basketball practice seems to impact the bone mineral density of adolescents significantly, but highlights the strong effect of variables related to growth and sexual maturation in this process ${ }^{19}$.

In the same context, the physical profile, physical abilities and hormonal markers and the relation with the bone age of this population group were compared. It was evidenced that the physical profile and motor performance differ according to the gender and maturational stage of children and adolescents, even in a similar age group. Bone age appeared related to motor performance in both the boys and the girls, especially the strength of the upper limbs, which showed a higher correlation with bone age ${ }^{20}$.

Silva et al. ${ }^{21}$ discussed the relationship between the motor stimulation opportunities in the family environment and children's motor development of both sexes. The home environment is directly related to the motor development of girls and boys. Being that the girls come from a home environment with a greater variety of stimulation, materials of fine and gross motricity; and boys residing in households with more fine and gross motor materials presented better levels of motor development.

Also in this issue of evaluation of growth and development, Gomes et al..$^{22}$ evaluated the pattern of growth and pubertal development of a group of patients with Sickle Cell Anaemia (SCA) from childhood to adulthood. Patients with SCA presented growth impairment and pubertal delay when compared to healthy controls. However, although late, they reached normal sexual maturation. In addition, they reached normal height in adulthood, unlike weight and BMI, which is even more evident in males.

The JHGD issue 27(1) also contemplates two articles that deal with postural deviations, aiming to estimate the prevalence of postural changes in the vertebral column of Brazilian schoolchildren through a systematic review with meta-analysis, noting that there is a low strength of evidence for establishing a consensus on the values of prevalence of postural deviations in the spine of students ${ }^{23}$, and the second focused on the analysis of the impact of bronchopulmonary dysplasia (BPD) on lung function of infants and preschool children from zero to 4 years of age $^{24}$, which indicated that neonates diagnosed early in life in the neonatal period with BPD have limited expiratory flow and reduced CRF when assessed in early childhood compared to term and preterm infants without BPD. Most new-borns, when they reach the age of five, present improvement in pulmonary function parameters, highlighting the direct effect of growth and development, as well as the acquisition of adequate weight for age.

Lastly, issue 27(1) makes a contribution in the field of adolescent vulnerability and the issue of abortion provided by law. It describes the situation of sexual violence and vulnerability in adolescence, as well as the clinical consequences of unsafe abortion and reports this experience, as well as sexual violence in situations of social and age vulnerability. It showed an attempted abortion with self-injury, revealing detrimental clinical effects and health problems of adolescents, reiterating the need for current issues in the field of Public Health and the care for the vulnerable population ${ }^{25}$.

Thus, issue 27(1) of the Journal of Human Growth and Development maintains the tradition of approaching the different aspects that involve the clinical practice of caring for people and public health, evidencing the real situation of the health conditions in the different contexts, from actions that seek to promote the health of the population to investigations that bring results that will improve the health situation of those involved, contributing to the (re)construction of health actions.

The importance of researches that can investigate better ways of achieving the reengineering of the health system is perceived, considering the medical demands of researchers, managers and patients/users, in order to produce new knowledge and these becoming products that will propitiate improvement of the health of the population, whether with a new diagnosis or new therapeutic treatments, or with actions aimed at promoting the health of the population. 
Therefore, even greater investment becomes necessary in financial terms and for personnel who can contribute to the development of innovative approaches, accelerating the transfer of knowledge, as well as encouraging the formation of interdisciplinary researchers who can establish network partnerships and exchanges, that are necessary for the development of translational medicine and public health contributions. researchers who can establish network partnerships and exchanges, that are necessary for the development of translational medicine and public health contributions.

\section{REFERENCES}

1. Lean MEJ, Mann JI, Hoek JA, ElliotRM, Schofield G. Translational research. BMJ. 2008;337:a863. DOI: https://doi.org/10.1136/bmj.a863

2. Pearson A, Jordan Z, Munn Z. Translational science and evidence-based healthcare: a clarification and reconceptualization of how knowledge is generated and used in healthcare. Nurs Res Pract. 2012;2012:1-6. DOI: http://dx.doi. org/10.1155/2012/792519

3. Elias FTS. Revisões sistemáticas da literatura e o potencial ganho em eficiência no Sistema Único de Saúde. Tese (Doutorado) - Universidade Federal de São Paulo. São Paulo: 2012.

4. Afonso L, Lopes C, Severo M, Santos S, Real H, Durão C, et al. Bidirectional association between parental childfeeding practices and body mass index at 4 and 7 y of age. Am J Clin Nutr. 2016; 103(3):861-7. DOI: http://dx.doi. org/10.3945/ajen.115.120824

5. Campbell-Grossman C, Hudson DB, Kupzyk KA, Brown SE, Hanna KM, Yates BC. Low-income, African American, adolescent mothers' depressive symptoms, perceived stress, and social support. J Child Family Studies. 2016;25(7):2306-14. DOI: http://dx.doi.org/10.1007/s10826-016-0386-9

6. Lumeng JC, Kaciroti N, Retzloff L, Rosenblum K, Miller AL. Longitudinal associations between maternal feeding and overweight in low-income toddlers. Appetite. 2017;113:23-9. DOI: http://dx.doi.org/10.1016/j.appet.2017.02.016

7. Shams B, Afshari E, Tajadini M, Keikha M, Qorbani5 M, Heshmat R, et al. The relationship of serum vitamin D and Zinc in a nationally representative sample of Iranian children and adolescents: The CASPIAN-III study. Med J Islam Repub Iran. 2016;30:430.

8. Spinelli MGN, Morimoto JM, Freitas APG, Barros CM, Dias DHS, Pioltine MB, et al. Estado nutricional e consumo alimentar de pré-escolares e escolares de escola privada. Rev Ciênc Saúde. 2013;6(2):94-101.

9. Paes ST, Marins JCB, Andreazzi AE. Efeitos metabólicos do exercício físico na obesidade infantil: uma visão atual. Rev Paul Pediatr. 2015;33(1):122-9. DOI: http://dx.doi.org/10.1016/j.rpped.2014.11.002

10. Moreira GAR, Vieira LJES, Deslandes SF, Pordeus MAJ, Gama IS, Brilhante AVM. Fatores associados à notificação de maus-tratos em crianças e adolescentes na atenção básica. Ciênc Saúde Coletiva, 2014; 19(10):4267-76. DOI: http://dx.doi.org/10.1590/1413-812320141910.17052013

11. Silva MF, Fontinele DRS, Oliveira AVS, Bezerra, MAR, Rocha SS. Determining factors of domestic accidents in early childhood. J Hum Growth Dev. 2017;27(1):11-19. DOI: http://dx.doi.org/10.7322/jhgd.127643

12. Zequinão MA, Cardoso AA, Silva JL, Medeiros P, Silva MAI, Pereira B, et al. School performance and bullying in socially vulnerable students. J Hum Growth Dev. 2017;27(1):20-26. DOI: http://dx.doi.org/10.7322/jhgd.127645

13. Coutinho BLM, Feitosa AA, Diniz CBC, Ramos JLS, Ribeiro LZ, et al. Alcohol And Drugs In Adolescence: Work Process In Health In School Program. J Hum Growth Dev. 2017;27(1):27-33. DOI: http://dx.doi.org/10.7322/ jhgd.127646

14. Freitas AG, Lima DG, Bortolini MJS, Meneguetti DUO, Santos EFS, Silva RPM. Comparison of the nutritional status in children aged fi ve to ten years old of the Conditional Cash Transfer Program in the States of Acre and Rio Grande do Sul, Brazil. J Hum Growth Dev. 2017;27(1):34-40. DOI: http://dx.doi.org/10.7322/jhgd.127647

15. Silva JP, Silva VR, Almeida PCD, Pinasco GC, Bernardes TP, Sasso JGRJ, et al. Growth and Nutritional Status Of Teens From Public State Education Network. J Hum Growth Dev. 2017;27(1):41-47. DOI: http://dx.doi.org/10.7322/ jhgd.127651

16. Araujo DM, Rovere NC, Lima MCMP. Development of infants with hearing impairment risk indicators and the environment classifi cation. J Hum Growth Dev. 2017;27(1):48-54. DOI: http://dx.doi.org/10.7322/jhgd.127652

17. Tebar WR, Vanderlei LCM, Scarabotollo CC, Zanuto EF, Saraiva BTC, Tebar FCSG, et al. Abdominal obesity: prevalence, sociodemographic and lifestyle-associated factors in adolescents. J Hum Growth Dev. 2017;27(1):55-62. DOI: http://dx.doi.org/10.7322/jhgd.127653

18. Santos VFA, Neves FS, Binoti ML, Mendes LL. Nutritional Quality of Snacks For Preschoolers Recommended On The Internet: Are They Healthy?. J Hum Growth Dev. 2017;27(1):63-69. DOI: http://dx.doi.org/10.7322/jhgd.127654

19. Rodrigues Júnior MA, Agostinete RR, Luiz-de-Marco R, Ito IH, Ribeiro-dos-Santos MR, Fernandes RA. Bone mineral density gains related to basketball practice in boys: 9 - month cohort. J Hum Growth Dev. 2017;27(1):70-75. DOI: http://dx.doi.org/10.7322/jhgd.127655 
20. Pinto VCM, Santos PGMD, Dantas MP, Araújo JPF, Cabral SAT, Cabral BGAT. Relationship Of Skeletal Age And Hormone Markers With Physical Capabilities Of Children And Adolescents. J Hum Growth Dev. 2017;27(1):76-82. DOI: http://dx.doi.org/10.7322/jhgd.127658

21. Silva WR, Lisboa T, Freitas KD, Ferrari EP, Cardoso FL, Motta NF, et al. Opportunities for motor stimulation in the home environment of children. J Hum Growth Dev. 2017;27(1):83-89. DOI: http://dx.doi.org/10.7322/jhgd.127659

22. Gomes IGP, Melo HN, Melo SIA, Vasconselos-de-Menezes N, Dantas TVP, Cipolotti R. Growth and Puberty In A Prospective Cohort Of Patients With Sickle Cell Anaemia: An Assessment Over Ten Years. J Hum Growth Dev. 2017;27(1):90-97. DOI: http://dx.doi.org/10.7322/jhgd.127681

23. Kasten AP, Rosa BN, Schmit EFD, Noll M, Candotti CT. Prevalence of postural changes in the spine in schoolchildren: a systematic review with meta-analysis. J Hum Growth Dev. 2017;27(1):98-107. DOI: http://dx.doi. org/10.7322/jhgd.127684

24. Scalco JC, Coelho R, Mucha FC, Schivinski CIS. Impact Of Bronchopulmonary Dysplasia On Pulmonary Function During Childhood: A Systematic Review. J Hum Growth Dev. 2017;27(1):108-114. DOI: http://dx.doi.org/10.7322/ jhgd. 127685

25. Silva ATM, Sousa GD, Lohmann CM, Ferreira Filho ES, Pinheiro WS, Soares Junior JM, et al. Vulnerability in Adolescence: A Case Report of Attempted Abortion and Sexual Violence. J Hum Growth Dev. 2017;27(1):115-122. DOI: http://dx.doi.org/10.7322/jhgd.127686 